\title{
Identifikasi Ketebalan Lapisan Lapuk pada Area Rawan Longsor Menggunakan Metode Seismik Refraksi (Studi Kasus: Desa Kalirejo Kabupaten Kulonprogo)
}

\author{
Muhardi $^{(1, a)^{*}}$, Radhitya Perdhana ${ }^{(1, b)}$, Muhammad Reza July Utama ${ }^{(2, c)}$, \\ Mitranikasih Laia $^{(3, \mathrm{~d})}$, Tisar Dewi Pratiwi ${ }^{(4, \mathrm{e})}$ dan Randha Ayu Nurwulandari ${ }^{(4, f)}$ \\ ${ }^{(1)}$ Prodi Geofisika, Universitas Tanjungpura, Pontianak, Indonesia, 78124 \\ ${ }^{(2)}$ Badan Meteorologi Klimatologi dan Geofisika, Jakarta, Indonesia, 10720 \\ ${ }^{(3)}$ Dinas Lingkungan Hidup, Kabupaten Nias Selatan, Indonesia, 22865 \\ ${ }^{(4)}$ Departemen Fisika, Universitas Gadjah Mada, Yogyakarta, Indonesia, 55281 \\ Email:( ${ }^{\left({ }^{*}\right)}$ muhardi@physics.untan.ac.id, ${ }^{(b)}$ radhitya.perdhana@physics.untan.ac.id, ${ }^{(c)}$ eemreza@gmail.com, \\ ${ }^{(d)}$ mitracheersly@gmail.com, ${ }^{(e)}$ tisardp@gmail.com, ${ }^{(f)}$ r3galzupz@gmail.com
}

Diterima (04 Februari 2020), Direvisi (15 Juli 2020)

\begin{abstract}
Kalirejo Village, Pengasih District, Kulonprogo Regency, is an area that is prone to landslides. The purpose of this study is to identify the weathering layer thickness, which is one of the triggering factors for landslides. This study was conducted using the seismic refraction method by applying two lines. Line 1 uses 24 geophones, has a distance of 1 meter between geophones, while Line 2 uses 24 geophones, has a distance of 2 meters between geophones. The results showed that the velocity of seismic wave propagation in the weathering layer for Line 1 was $400 \mathrm{~m} / \mathrm{s}$, and in the slip surface was 2,300 m/s. The weathering layer thickness on Line 1 is 7.6 - 9.8 meters and the slope is steep so that this location is predicted to have a potential landslide. While the velocity of seismic wave propagation in the weathering layer for Line 2 was $300 \mathrm{~m} / \mathrm{s}$, and in the slip surface was $2,200 \mathrm{~m} / \mathrm{s}$. The weathering layer thickness on Line 2 is at less than 2 meters, so this location is predicted not to have a landslide potential even though the slope is steep.
\end{abstract}

Keywords: Weathering Layer, Landslides, Seismic Method, Refraction, Kalirejo Village

Abstrak. Desa Kalirejo Kecamatan Pengasih Kabupaten Kulonprogo merupakan daerah yang rawan terhadap bencana longsor. Tujuan penelitian ini adalah untuk mengidentifikasi ketebalan lapisan lapuk yang menjadi salah satu faktor pemicu terjadinya longsor. Penelitian ini dilakukan menggunakan metode sesmik refraksi dengan mengaplikasikan dua lintasan. Lintasan 1 menggunakan 24 geofon dengan jarak antar geofon sejauh 1 meter, sedangkan lintasan 2 menggunakan 24 geofon dengan jarak antar geofon sejauh 2 meter. Hasil penelitian menunjukkan bahwa kecepatan perambatan gelombang seismik pada lapisan lapuk untuk lintasan 1 sebesar $400 \mathrm{~m} / \mathrm{s}$ dan pada bidang gelincir sebesar $2.300 \mathrm{~m} / \mathrm{s}$. Ketebalan lapisan lapuk pada lintasan 1 yaitu 7,6 - 9,8 meter dan kemiringan lerengnya cukup terjal, sehingga lokasi ini diprediksi berpotensi longsor. Sedangkan kecepatan perambatan gelombang seismik pada lapisan lapuk untuk lintasan 2 sebesar $300 \mathrm{~m} / \mathrm{s}$ dan pada bidang gelincir sebesar $2.200 \mathrm{~m} / \mathrm{s}$. Ketebalan lapisan lapuk pada lintasan 2 yaitu kurang dari 2 meter, sehingga lokasi ini diprediksi tidak berpotensi longsor walaupun kemiringan lerengnya cukup terjal.

Kata kunci: Lapisan Lapuk, Longsor, Metode Seismik, Refraksi, Desa Kalirejo 


\section{PENDAHULUAN}

Kabupaten Kulonprogo merupakan daerah rawan longsor[1]. Potensi bencana tanah longsor terdapat di lima kecamatan yaitu Kecamatan Pengasih, Girimulyo, Kokap, Samigaluh, dan Kalibawang. Kecamatan Kokap dikenal sebagai daerah yang sering terjadi bencana longsor[2]. Desa Kalirejo merupakan salah satu desa yang berada di Kecamatan Kokap dan berada di perbukitan Menoreh yang banyak memiliki tebing tinggi. Secara umum area rawan longsor berada pada daerah yang berbatasan langsung dengan tebing jalan, lembah sungai, gawir, dan lereng gunung. Sebagai salah satu langkah mitigasi, perlu dilakukan penelitian pada area yang dianggap berpotensi terjadinya bencana longsor, agar dapat mengurangi kerugian yang dapat ditimbulkan.

Longsor dapat terjadi karena adanya gangguan kestabilan pada lereng akibat kondisi geologi, hidrologi, topografi, iklim, dan perubahan cuaca[3]. Penyebab longsor diantaranya adalah berupa faktor pemicu longsor dan pengontrol kestabilan lereng [4]. Kestabilan lereng sangat dipengaruhi oleh kemiringan, tanah penyusun[5], dan kondisi hidrologi pada lereng. Lereng perbukitan yang terjal dan berpotensi longsor belum akan terjadi pergerakan tanah jika tidak ada faktor pemicu, misalnya gempa dan hujan.

Longsor juga dipengaruhi oleh ketebalan lapisan lapuk, karena lapisan ini dapat berperan sebagai material longsor, yang umumnya bergerak pada bidang gelincir[6]. Bidang ini merupakan batas antara lapisan yang stabil dan lapisan yang tidak stabil (material longsor), dan secara umum berada di bawah lapisan lapuk[7]. Lapisan lapuk terbentuk karena adanya proses pelapukan (weathering), yaitu proses perubahan ukuran batuan menjadi lebih kecil, yang diakibatkan oleh pengaruh kondisi cuaca, temperatur, kelembaban, air, maupun aktivitas organisme.
Proses pelapukan pada material batuan di permukaan bumi akan mengaki-batkan perubahan pada sifat batuan, baik secara fisika maupun kimia. Proses pelapuk-an akan menghasilkan produk pelapukan pada regolith karena adanya interaksi dengan air dan udara. Proses pelapukan menjadi faktor penting dalam menentukan stabilitas lereng karena dapat mempengaruhi kekuatan regolith dan daya serap air.

Penelitian terhadap ketebalan lapisan lapuk dinilai efektif jika dilakukan dengan survei geofisika, salah satunya menggunakan metode seismik refraksi[8], karena dapat mengetahui penampang struktur bawah permukaan yang relatif dangkal[9]. Metode ini dapat mengidentifikasi kecepatan gelombang seismik yang merambat di bawah permukaan pada setiap lapisan[10]. Metode ini diaplikasikan berdasarkan perambatan gelombang seismik di bawah permukaan yang mempunyai sifat pembiasan (refraksi) jika mengenai parameter fisis yang berbeda (bidang batas antar lapisan) dengan sudut kritis tertentu. Sifat pembiasan ini akan terjadi jika lapisan yang berada di bawahnya akan merambatkan gelombang seismik dengan kecepatan yang lebih besar dibandingkan dengan lapisan yang berada di atasnya[11].

\section{METODE PENELITIAN}

Penelitian dilakukan di Jalan Sangon, Desa Kalirejo, Kecamatan Kokap, Kabupa-ten Kulonprogo, yaitu berada pada koordinat $110^{\circ} 03^{\prime} 29,45^{\prime \prime}$ BT hingga $110^{\circ} 04^{\prime} 19,33^{\prime \prime}$ BT dan $7^{0} 49^{\prime} 44,18^{\prime \prime}$ LS hingga $7^{0} 50^{\prime} 14,05^{\prime \prime}$ LS. Pengambilan data dilakukan pada lereng perbukitan di dua lokasi yang berbeda, seperti pada Gambar 1. Pada masingmasing lokasi diaplikasikan satu lintasan dengan menggunakan metode seismik refraksi. 


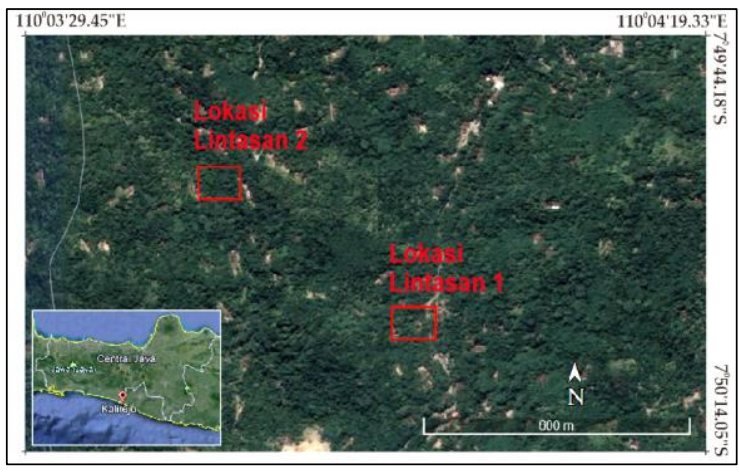

Gambar 1. Lokasi penelitian

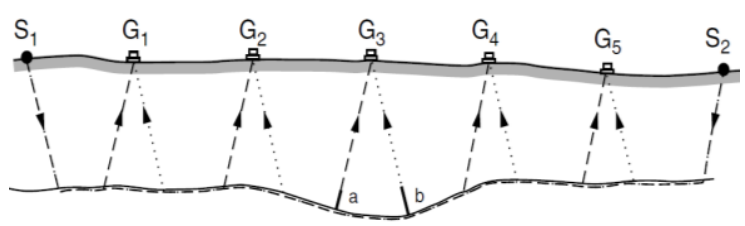

Gambar 2. Ilustrasi proses akuisisi data[12]

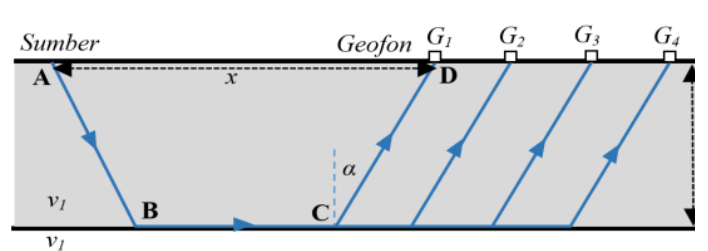

Gambar 3. Ilustrasi perambatan gelombang seismik rerfaksi[9].

Akuisisi data seismik refraksi menggunakan beberapa buah geofon (geophone) dengan menerapkan model bentang segaris berupa lintasan (in line) seperti Gambar 2. Gelombang seismik yang berasal dari sumber getaran $(\mathrm{S})$ direkam oleh geofon $(\mathrm{G})$ dan ditampilkan dengan menggunakan Software Doremi. Hasil rekaman ini berupa data waktu tempuh gelombang seismik (travel time) yang merambat di bawah permukaan pada setiap lapisan.

Jika jarak antar geofon dan waktu tempuh perambatan gelombang seismik diketahui, maka ketebalan lapisan bawah permukaan dapat diprediksi berdasarkan besar kecepatannya[10,11]. Kemudian akan dilakukan picking pada gelombang pertama (first break)[12,13], sehingga diperoleh waktu tiba (time break) dan ditampilkan dalam kurva waktu tempuh terhadap jarak antar geofon (kurva $\mathrm{t}-\mathrm{x}$ ), kemudian dilakukan proses interpretasi.

Waktu tiba gelombang seismik pada penelitian ini diperoleh dengan perhitungan menggunakan metode Hagiwara[17]. Metode ini umumnya mengasumsikan undulasi bawah permukaan tidak terlalu besar, dan mempunyai kelebihan yaitu dapat menampilkan kontur bidang lapisan bawah permukaan [18]. Metode ini dapat diaplikasikan dengan mudah terutama pada struktur sederhana yang hanya terdiri atas dua lapisan dengan kerapatan berbeda[19]. Perbedaan kerapatan akan berdampak pada perbedaan kecepatan perambatan gelombang seismik di setiap lapisan. Bidang batas antar lapisan akan digambarkan dengan kedalaman rata-rata, karena gelombang seismik akan dibiaskan pada bidang batas tersebut.

Perambatan gelombang seismik di bawah permukaan dan pembiasan pada bidang batas seperti pada Gambar 3. Jika gelombang seismik yang bersumber dari sumber getaran (shot point) A, maka gelombang tersebut akan mengalami pembiasan pada bidang batas antar lapisan tersebut (B-C). Waktu tiba dapat dideteksi dengan geofon $\mathrm{D}$, dan dapat dituliskan dengan Persamaan 1.

$$
t=\frac{A B+C D}{v_{1}}+\frac{B C}{v_{2}}
$$

dengan $t=$ waktu perambatan gelom-bang dari $\mathrm{A}$ ke $\mathrm{D}(\mathrm{s}), \mathrm{AB}=$ lintasan perambatan gelombang dari titik A ke B pada lapisan 1 $(\mathrm{m}), \mathrm{CD}=$ lintasan perambatan gelombang dari titik $\mathrm{C}$ ke D pada lapisan $1(\mathrm{~m}), \mathrm{BC}=$ lintasan perambatan gelombang pada lapisan $2(\mathrm{~m}), \quad v_{1}=$ kecepatan perambatan gelombang pada lapisan $1(\mathrm{~m} / \mathrm{s}), v_{2}=$ kecepatan pe-rambatan gelombang pada lapisan $2(\mathrm{~m} / \mathrm{s})$.

Pada sudut kritis, gelombang seismik akan dibiaskan dengan sudut $90^{\circ}$, sehingga berlaku $\sin \alpha=v_{1} / v_{2}$ (Hukum Snellius) 
Muhardi dkk: Identifikasi Ketebalan Lapisan Lapuk pada Area Rawan Longsor Menggunakan Metode Seismik Refraksi (Studi Kasus: Desa Kalirejo Kabupaten Kulonprogo)

[19], dan waktu tiba dapat dituliskan dengan Persamaan 2.

$$
t=\frac{2 v_{1} \cos \alpha}{v_{1}}+\frac{x}{v_{2}}
$$

dengan $x=$ jarak antara sumber dengan geofon (m). Jika $x=0$, maka waktu yang dibutuhkan gelombang untuk merambat

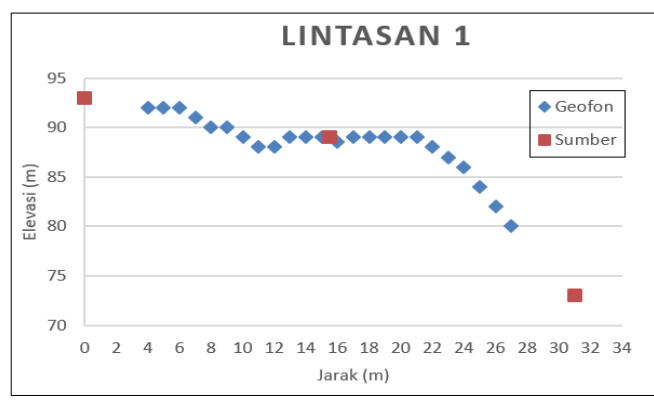

(a) disebut intercept time $\left(t_{i}\right)$, sehingga ketebalan lapisan pertama $\left(z_{1}\right)$ dapat dituliskan dengan Persamaan 3.

$$
z_{1}=\frac{t_{i} v_{1} v_{2}}{2 \sqrt{v_{2}^{2}-v_{1}^{2}}}
$$

dengan $t_{i}=$ intercept time $(\mathrm{s}), z_{1}=$ ketebalan lapisan $1(\mathrm{~m})$.

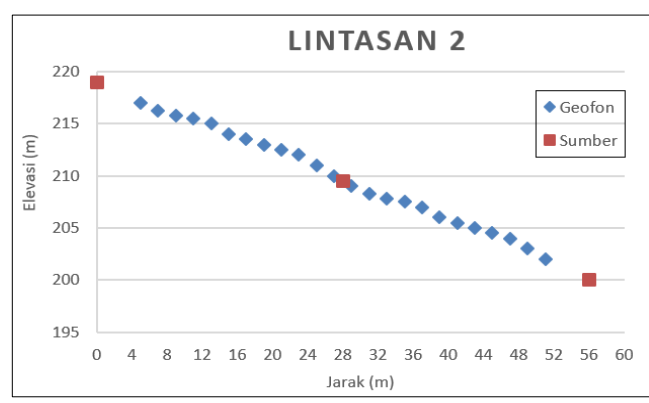

(b)

Gambar 4. Jarak geofon dan sumber (shot point) pada topografi di lokasi penelitian; (a) lintasan 1, (b) lintasan 2

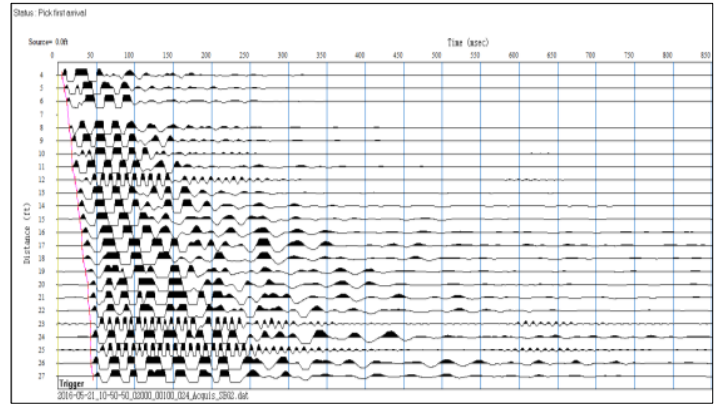

(a)

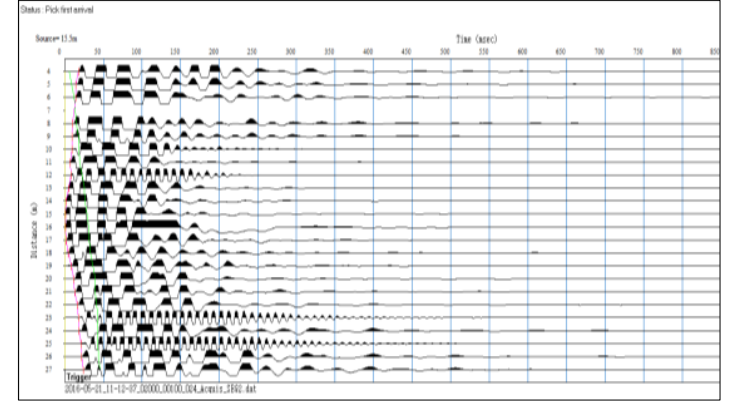

(b)

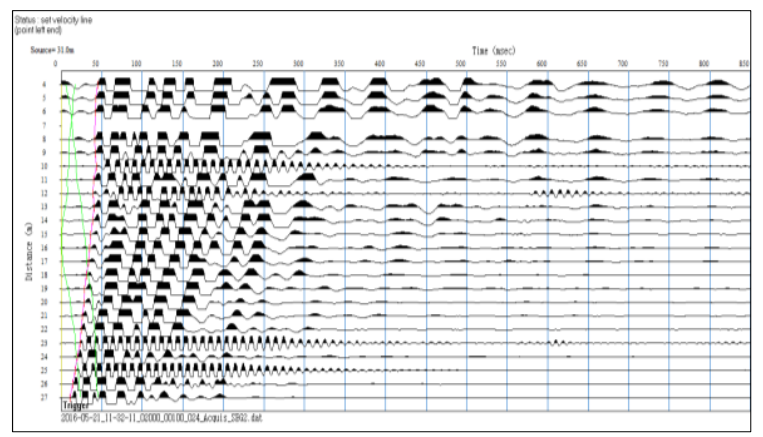

(c)

Gambar 5. Hasil picking waktu tiba gelombang per-tama setiap geofon pada lintasan 1 (a) shot 1, (b) shot 2, (c) shot 3 . 


\section{HASIL DAN PEMBAHASAN}

Akuisisi data dilakukan pada dua lokasi dengan dua lintasan. Lintasan 1 dila-kukan di lokasi pertama yang berada pada elevasi 73 - 93 meter. Jarak antar geofon sebesar 1 meter, dan sumber (shot point) dilakukan sebanyak 3 kali, 1 titik di tengah dan 2 titik secara forward dan reverse de-ngan jarak masing-masing 3 meter (Gambar 4.a). Sedangkan Lintasan 2 dilakukan di lokasi kedua yang berada pada elevasi 200 - 2018 meter. Jarak antar geofon sebesar 2 meter, dan sumber (shot point) dilakukan sebanyak 3 kali, 1 titik di tengah dan 2 titik secara forward dan reverse dengan jarak masingmasing 5 meter (Gambar 4.b).

Penentuan waktu tiba gelombang pertama setiap geofon pada lapisan 1 seperti pada Gambar 5. Data yang diperoleh dari proses picking pada gelombang pertama ditunjukkan dengan garis merah.

Setelah dilakukan picking maka dapat dibuat kurva $\mathrm{t}-\mathrm{x}$ untuk menunjukkan hubungan jarak dan waktu tiba gelombang pada setiap geofon dari 3 sumber seismik. Adapun kurva $\mathrm{t}-\mathrm{x}$ hasil picking pada lintasan 1 seperti pada Gambar 6.

Sedangkan penentuan waktu tiba gelombang pertama setiap geofon pada lapisan 2 seperti pada Gambar 7. Data yang diperoleh dari proses picking pada gelombang pertama ditunjukkan dengan garis merah.

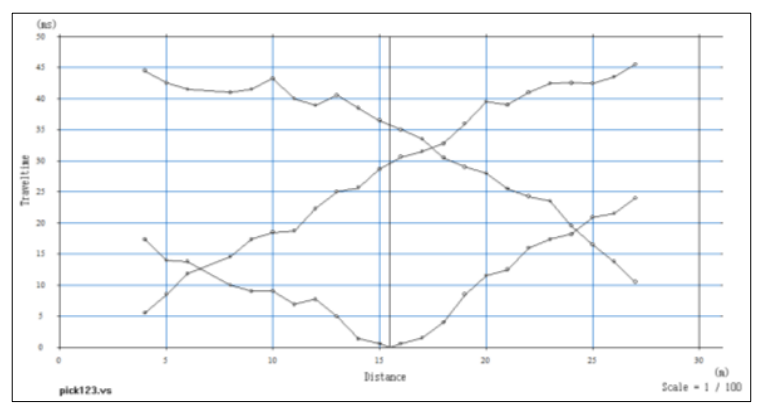

Gambar 6. Kurva t-x hasil picking pada lintasan 1

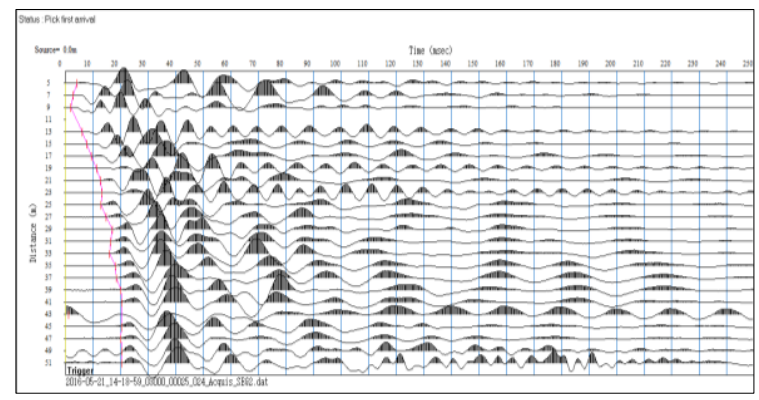

(a)

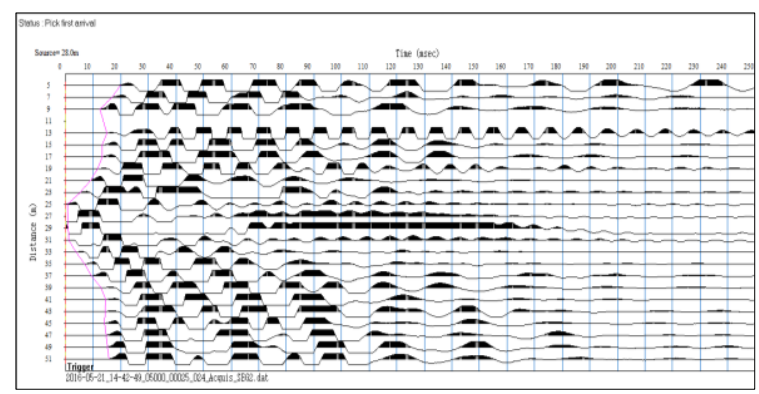

(b)

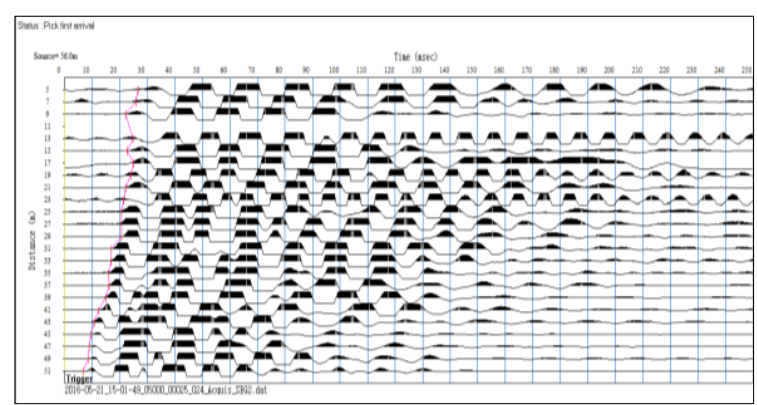

(c)

Gambar 7. Hasil picking waktu tiba gelombang pertama setiap geofon pada lintasan 2; (a) shot 1, (b) shot 2, (c) shot 3

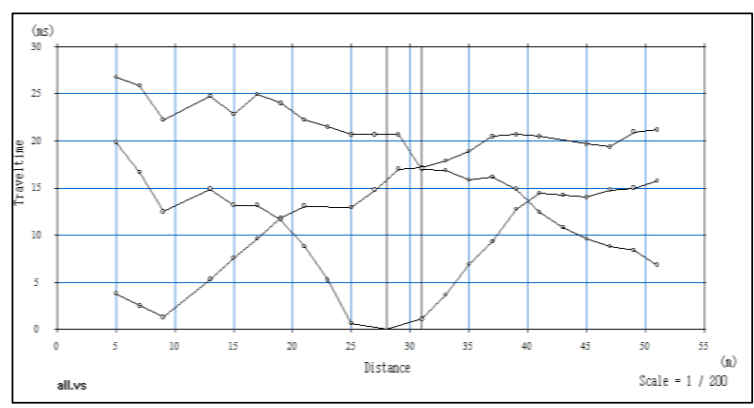

Gambar 8. kurva t-x hasil picking pada lintasan 2

Setelah dilakukan picking maka dapat dibuat kurva $\mathrm{t}-\mathrm{x}$ untuk menunjukkan hubungan jarak dan waktu tiba gelombang pada setiap geofon dari 3 sumber seismik. Adapun kurva t-x hasil picking pada lintasan 1 seperti diperlihatkan pada Gambar 8. 
Dari hasil pengolahan data pada lintasan 1, dapat diidentifikasi kecepatan perambatan gelombang seismik pada lapisan pertama yaitu $v_{1}=470 \mathrm{~m} / \mathrm{s}$, sedangkan pada lapisan kedua yaitu $v_{2}=2.375 \mathrm{~m} / \mathrm{s}$. Gambar 9 menunjukkan bahwa lapisan pertama berwarna coklat yang diinterpretasi berupa lapisan lapuk, sementara lapisan di bawahnya berwarna biru yang diinterpretasi berupa bidang gelincir.

Perbedaan kecepatan antara lapisan lapuk dan bidang gelincir yang berada di bawahnya menunjukkan bahwa bidang gelincir pada lintasan 1 mempunyai litologi yang lebih solid dibandingkan lapisan lapuk sehingga dapat merambatkan gelombang seismik dengan kecepatan yang lebih besar yaitu $2.375 \mathrm{~m} / \mathrm{s}$. Hasil penelitian juga menunjukkan bahwa lintasan 1 pada posisi 4 meter hingga 21 meter, mempunyai kemiringan lereng yang tidak terlalu terjal ke arah Tenggara. Kondisi lereng dari posisi 21 meter hingga 27 meter memiliki kemiringan yang cukup terjal.

Hal tersebut menunjukkan bahwa lokasi lintasan 1 memiliki potensi longsor, terutama dari posisi 21 meter yang berdekatan dengan posisi jalan. Lintasan 1 memiliki ketebalan lapisan lapuk sebesar 7,6 meter hingga 9,8 meter. Kondisi kemiringan lereng yang cukup terjal terutama mulai dari jarak lintasan 21 meter menunjukkan bahwa material tanah pada lapisan lapuk berpotensi untuk bergerak, sehingga dapat mengakibatkan longsor.

Sedangkan dari hasil pengolahan data pada lintasan 2, dapat diidentifikasi kecepatan perambatan gelombang seismik pada lapisan pertama yaitu $v_{1}=300 \mathrm{~m} / \mathrm{s}$, sedangkan pada lapisan kedua yaitu $v_{2}=$ 2.300 m/s. Gambar 10 menunjukkan bahwa lapisan pertama berwarna ungu yang diinterpretasi berupa lapisan lapuk, sementara lapisan di bawahnya berwarna biru tua yang diinterpretasi berupa bidang gelincir.

Perbedaan kecepatan antara lapisan lapuk dan bidang gelincir yang berada di bawahnya menunjukkan bahwa bidang gelincir pada lintasan 2 mempunyai litologi yang lebih solid dibandingkan lapisan lapuk, sehingga dapat merambatkan gelombang seismik dengan kecepatan yang lebih besar yaitu $2.300 \mathrm{~m} / \mathrm{s}$. Hasil penelitian juga menunjukkan bahwa lintasan 2 mempunyai kemiringan lereng yang cukup terjal ke arah Barat.

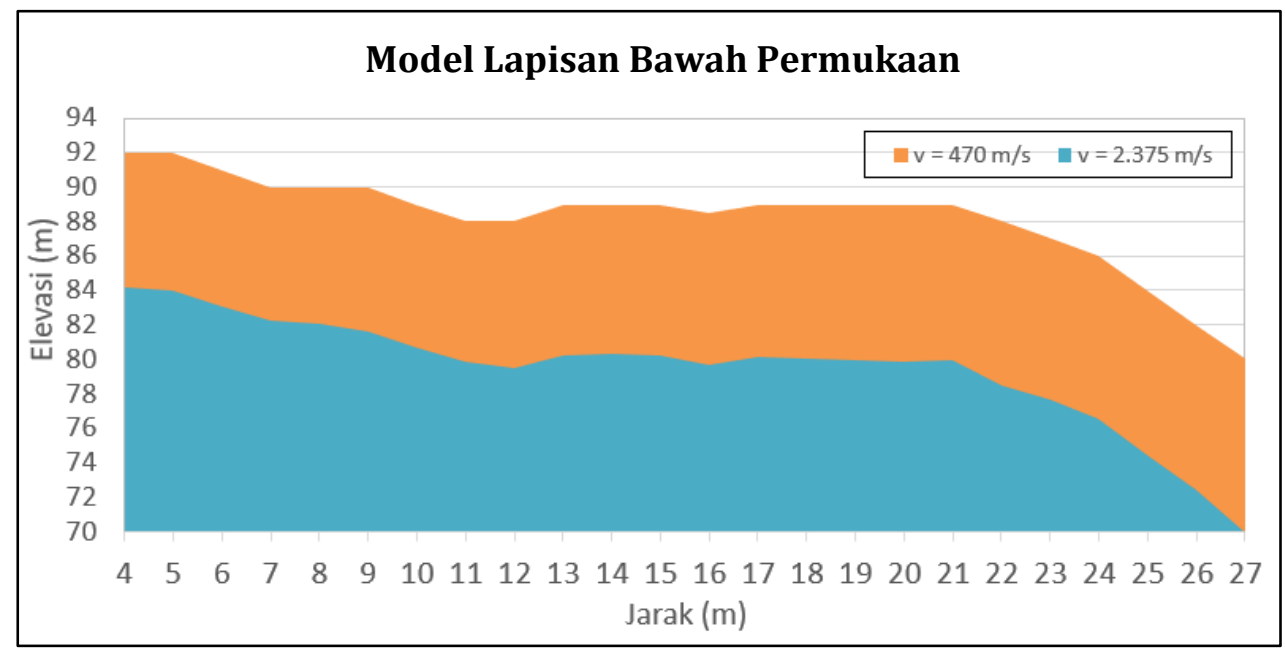

Gambar 9. Model lapisan bawah permukaan pada Lintasan 1 


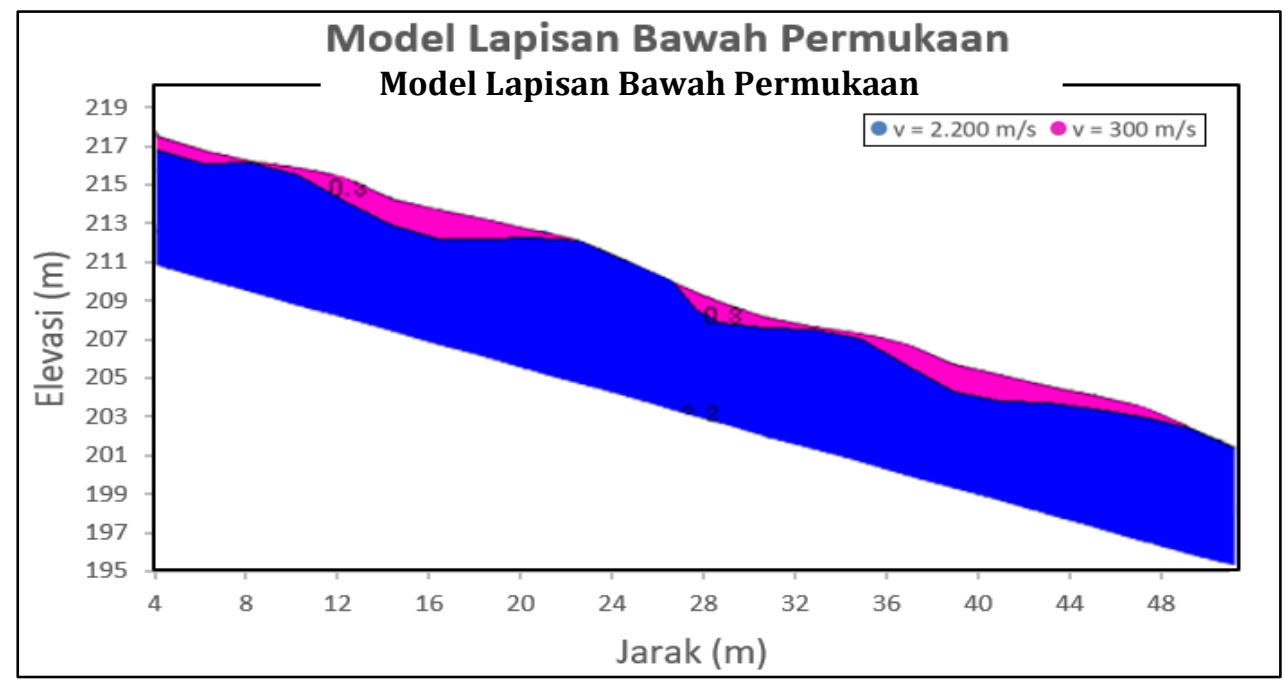

Gambar 10. Model lapisan bawah permukaan pada Lintasan 2

Lintasan 2 memiliki ketebalan lapis-an lapuk yang cukup tipis yaitu kurang dari 2 meter. Bidang gelincir yang berada di bawahnya terlihat memiliki struktur yang berundak. Ini sesuai dengan yang diamati di lapangan, yaitu terdapat beberapa singkapan lapisan keras yang terlihat di permukaan. Dengan demikian, lintasan 2 berada pada lokasi yang relatif lebih stabil dan tidak berpotensi longsor walaupun lebih terjal dibandingkan dengan lokasi lintasan 1.

\section{KESIMPULAN}

Hasil penelitian pada lintasan 1 menunjukkan bahwa kecepatan perambatan gelombang seismik pada lapisan lapuk sebesar $400 \mathrm{~m} / \mathrm{s}$ dan bidang gelincir sebesar $2.300 \mathrm{~m} / \mathrm{s}$. Ketebalan lapisan lapuk yaitu 7,6 - 9,8 meter dan kemiringan lerengnya cukup terjal, sehingga lokasi ini berpotensi longsor terutama yang berdekatan dengan posisi jalan. Sedangkan pada lintasan 2 menunjukkan bahwa kecepatan perambatan gelombang seismik pada lapisan lapuk sebesar 300 $\mathrm{m} / \mathrm{s}$ dan bidang gelincir sebesar $2.200 \mathrm{~m} / \mathrm{s}$. Ketebalan lapisan lapuk diketahui cukup tipis yaitu kurang dari 2 meter, sehingga lokasi ini tidak berpotensi longsor walaupun kemiringan lerengnya cukup terjal.

\section{DAFTAR PUSTAKA}

[1] O. Trianda, R. Prastowo, and S. Novitasari, "Identifikasi Ketebalan Lapisan Lapuk di Daerah Kalirejo, Kulonprogo Berdasarkan Pengukuran Mikrotremor dalam Upaya Mitigasi Tanah Longsor," in Prosiding Nasional Rekayasa Teknologi Industri dan Informasi XIII, 2018, pp. 246253.

[2] A. A. J. Permana and P. P. K. Wiguna, "Tanah Longsor: Memperkecil Resiko Bencana Menggunakan Sistem Informasi Geografis (Studi Kasus : Kecamatan Kokap, Kulon Progo, DIY)," J. Pendidik. Teknol. dan Kejuru., vol. 9, no. 1, pp. 47-60, 2012.

[3] H. C. Hardiatmo, Tanah Longsor dan Erosi, Kejadian dan Penanganan. Yogyakarta: Gadjah Mada University Press, 2012.

[4] Misbahuddin, A. Husna, R. Toriq, and A. Marwanto, "Analisis Kerentanan Longsoran Menggunakan Proses Hirarki Analitik di Daerah Sukatani dan Sekitarnya, Kabupaten Purwakarta, Jawa Barat," J. Lingkung. 
dan Bencana Geol., vol. 8, no. 1, pp. 19-30, 2017.

[5] V. G. M. Pangemanan, "Analisis Kestabilan Lereng dengan Metode Fellenius (Studi Kasus: Kawasan Citraland)," J. Sipil Statik, vol. 2, no. 1, pp. 37-46, 2014.

[6] N. Priyantari and A. Suprianto, "Penentuan Kedalaman Bedrock Menggunakan Metode Seismik Refraksi di Desa Kemuning Lor Kecamatan Arjasa Kabupaten Jember," J. Ilmu Dasar, vol. 10, no. 1, pp. 6-12, 2009.

[7] Darsono, B. Nurlaksito, and B. Legowo, "Identifikasi Bidang Gelincir Pemicu Bencana Tanah Longsor dengan Metode Resistivitas 2 Dimensi di Desa Pablengan Kecamatan Matesih Kabupaten Karanganyar," Indones. J. Appl. Phys., vol. 2, no. 1, pp. 51-60, 2012.

[8] V. Y. Artono, R. Efendi, and Sandra, "Identifikasi Lapisan Lapuk Bawah Permukaan Menggunakan Seismik Refraksi di Desa Lengkeka Kecamatan Lore Barat Kabupaten Poso," J. Sci. Technol., vol. 6, no. 3, pp. 291-300, 2017.

[9] W. M. Telford, L. P. Geldart, and R. E. Sheriff, Applied Geophysics, $2^{\text {th }}$ Ed. New York: Cambridge University Press, 1990.

[10] M. E. Everett, Near-Surface Applied Geophysics. New York: Cambridge University Press, 2013.

[11] B. A. Wibowo, D. Ngadmanto, Z. Listyaningrum, Y. Mahardika, and K. Putra, "Identifikasi Lapisan Rawan Longsor Menggunakan Metode
Seismik Refraksi Studi Kasus: Kampus Lapangan LIPI Karangsambung," in Prosiding Seminar Nasional Fisika, 2015, no. 4, pp. 18-24.

[12] J. Milsom, Field Geophysics, $3^{\text {th }}$ Ed. England: Wiley, 2002.

[13] S. Utami and Supriyadi, "Identifikasi Potensi Longsor Menggunakan Metode Seismik Refraksi di Kawasan Wisata Nglimut Desa Gonoharjo Limbangan Kendal," Unnes Phys. J., vol. 3, no. 2, pp. 51-57, 2014.

[14] N. Nurcandra and S. Koesuma, "Penentuan Tingkat Kekerasan Batuan Menggunakan Metode Seismik Refraksi di Jatikuwung Karanganyar," Indones. J. Appl. Phys., vol. 3, no. 1, pp. 29-35, 2013.

[15] B. Nurdiyanto, E. Hartanto, D. Ngadmanto, B. Sunardi, and P. Susilanto, "Penentuan Tingkat Kekerasan Batuan Menggunakan Metode Seismik Refraksi," $J$. Meteorol. dan Geofis., vol. 12, no. 3, pp. 211-220, 2011.

[16] M. N. I. Rahmawati, B. Legowo, and A. D. Sutomo, "Identifikasi Batuan Dasar (Bedrock) Menggunakan Metode Seismik Refraksi di Lokasi Pendirian Rumah Sakit Pendidikan Universitas Sebelas Maret," Indones. J. Appl. Phys., vol. 4, no. 1, pp. 28-31, 2014.

[17] S. N. Hudha, U. Harmoko, S. Widada, D. H. Yusuf, G. Yulianto, and Sahid, "Penentuan Struktur Bawah Permukaan dengan Menggunakan Metode Seismik Refraksi di Lapangan Panas Bumi Diwak dan Derekan, Kecamatan Bergas, Kabupaten 
Semarang," Youngster Phys. J., vol. 3, no. 3, pp. 263-268, 2014.

[18] Refrizon, Suwarsono, and K. Natalia, "Visualisasi Struktur Bawah Permukaan dengan Metode Hagiwara," J. Gradien, pp. 30-33, 2009.
[19] Sismanto, Pengantar Survei dengan Menggunakan Gelombang Seismik. Yogyakarta: Gerbang Media Aksara, 2016. 
Muhardi dkk: Identifikasi Ketebalan Lapisan Lapuk pada Area Rawan Longsor Menggunakan Metode Seismik Refraksi (Studi Kasus: Desa Kalirejo Kabupaten Kulonprogo) 